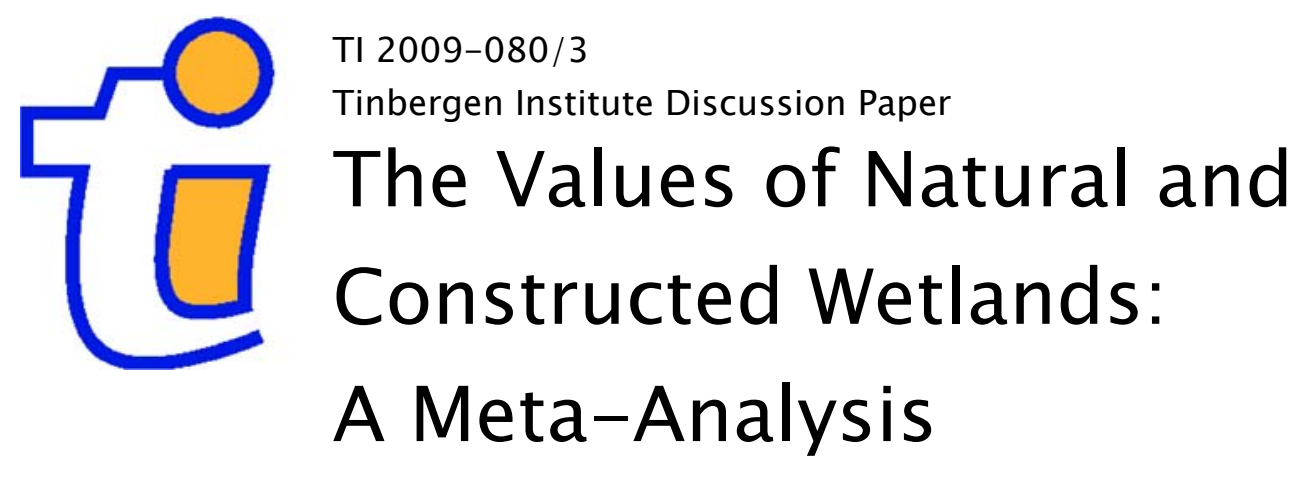

\author{
Andrea Ghermandil,6 \\ Jeroen C.J.M. van den Bergh²,4,5 \\ Luke M. Brander 3 \\ Henri L.F. de Groot ${ }^{2,5}$ \\ Paulo A.L.D. Nunes',6
}

' Zuckerberg Institute for Water Research, Ben-Gurion University of the Negev, Israel;

2 Dept. of Spatial Economics, VU University Amsterdam, The Netherlands;

3 Institute for Environmental Studies (IVM), VU University Amsterdam, The Netherlands;

4 Institute for Environmental Science and Technology, Universitat Autonoma de Barcelona, Spain;

5 Tinbergen Institute, The Netherlands;

${ }^{6}$ Fondazione Eni Enrico Mattei (FEEM), Venice, Italy. 


\section{Tinbergen Institute}

The Tinbergen Institute is the institute for economic research of the Erasmus Universiteit Rotterdam, Universiteit van Amsterdam, and Vrije Universiteit Amsterdam.

Tinbergen Institute Amsterdam

Roetersstraat 31

1018 WB Amsterdam

The Netherlands

Tel.: +31(0)205513500

Fax: $+31(0) 205513555$

Tinbergen Institute Rotterdam

Burg. Oudlaan 50

3062 PA Rotterdam

The Netherlands

Tel.: + $31(0) 104088900$

Fax: $+31(0) 104089031$

Most TI discussion papers can be downloaded at http://www.tinbergen.nl. 


\title{
The Values of Natural and Constructed Wetlands: A Meta-analysis
}

\author{
Andrea Ghermandi ${ }^{1,6}$, Jeroen C.J.M. van den Bergh ${ }^{2,4,5}$, Luke M. Brander ${ }^{3}$ \\ Henri L.F. de $\operatorname{Groot}^{2,5, *}$ and Paulo A.L.D. Nunes ${ }^{1,6}$ \\ ${ }^{1}$ Zuckerberg Institute for Water Research, Ben-Gurion University of the Negev, Israel \\ ${ }^{2}$ Department of Spatial Economics, VU University Amsterdam, The Netherlands \\ ${ }^{3}$ Institute for Environmental Studies (IVM), VU University Amsterdam, The Netherlands \\ ${ }^{4}$ Institute for Environmental Science and Technology, Universitat Autonoma de Barcelona, Spain \\ ${ }^{5}$ Tinbergen Institute, Amsterdam-Rotterdam, The Netherlands \\ ${ }^{6}$ Fondazione Eni Enrico Mattei (FEEM), Venice, Italy
}

\begin{abstract}
The values of goods and services provided by natural and constructed wetlands are examined through a meta-analysis of 418 observations of the economic value of 186 wetlands. Water quality improvement, non-consumptive recreation, and provision of natural habitat and biodiversity turn out to be highly valued services. Substitution effects are observed through the negative correlation between values and proximity to other wetlands. Values are found to increase with anthropogenic pressure. Constructed wetlands are highly valued for biodiversity enhancement, water quality improvement, and flood control. This study provides a substantially new contribution in relation to previous meta-analyses of the wetland valuation literature.
\end{abstract}

Keywords: constructed ecosystems, economic valuation, constructed wetlands, meta-regression, wetland values

JEL classification: C81, Q24

\footnotetext{
* Corresponding author: Henri L.F de Groot, VU University, Dept. of Spatial Economics, De Boelelaan 1105, 1081 HV Amsterdam, The Netherlands. Email: hgroot@feweb.vu.nl. We are grateful to the Department of Spatial Economics at the VU University Amsterdam and FEEM for the logistic support. In addition, we would like to thank Kerry Smith and all the participants of the IX annual meeting of the Biodiversity and Economics for Conservation Network (BIO.ECON) for their valuable comments on a previous version of this paper. Finally, we would like to thank the European Investment Bank for financial support.
} 


\section{Introduction}

The recognition of the wide range of ecological and economic benefits that natural wetland ecosystems provide to humans (Turner 1991) has prompted increasing interest in the construction of human-made wetland ecosystems, which simulate the functions of natural wetlands in order to support human use (Hammer and Bastian 1989). Wetland ecosystems are generally constructed with the aim of replicating wetland processes such as water storage, flood retention, and water quality improvement for human benefit (Kadlec and Knight 1996). They may also be created with the broader aim of mimicking the foregone ecological functions of lost natural wetland ecosystems and compensating the destruction of natural habitats, such as mitigation wetlands constructed under the "no net loss of wetlands" policy in the USA (White House Office on Envtl. Policy 1993).

Purposefully planned, designed and operated human-made wetlands may provide a range of services well beyond the primary aim for their construction. Ancillary benefits of wastewater treatment wetlands may include, for instance, provision of habitat and wildlife diversity, support of recreational activities such as walking, bird- and wildlife watching, water storage during periods of shortage and excess, and aesthetic value in urban environments (Benyamine et al. 2004; Knight 1997; Knight et al. 2001). Comparative studies investigating the ecological functions of both natural and constructed wetlands suggest that they fulfill similar ecological functions, even though constructed wetlands tend to resemble degraded natural wetlands rather than undisturbed reference ecosystems (Campbell et al. 2002; Brooks et al. 2005; Confer and Niering 1992; Balcombe et al. 2005).

In this study, we use the technique of meta-analysis to investigate the provision of services of wetland ecosystems from an economic perspective and with a focus on the valuation of human-made wetlands. Meta-analysis has been extensively used in environmental economics as a tool to synthesize the findings of primary valuation studies by means of a rigorous statistical analysis (Bal and Nijkamp 2001). Best-practice guidelines for meta-analysis were developed (Stanley 2005; Nelson and Kennedy 2008) in order to deal with potential issues related to the heterogeneity of the environmental resources and economic instruments considered (Smith and Pattanayak 2002), selection bias (Hoehn 2006), heteroscedasticity, and correlation between observations (Rosenberger and Loomis 2000). The potential of meta-analysis in identifying the sources of variation in empirical value estimates (Johnston et al. 2003; Scheierling et al. 2006) and as a tool for value transfer (Bergstrom and Taylor 2006; Rosenberger and Loomis 2000) is generally acknowledged. Three previous meta-analyses of wetland values (Brander et al. 2006; Brouwer et al. 1999; 
Woodward and Wui 2001) provided a solid conceptual and empirical basis for the present investigation.

The objectives of this study are twofold. First, we aim at improving the general understanding of both natural and constructed wetland values by conducting a meta-analysis that extends previous models with explanatory variables, such as the presence of substitute sites and the anthropogenic pressure exercised on the wetlands, which are chosen in order to get a better and more economically oriented explanation of observed differences in wetland valuations. The meta-analysis relies on a comprehensive dataset of 418 value observations derived from 170 valuation studies and 186 wetland sites worldwide. Second, we explore the variation in the valuation of constructed wetlands by means of a meta-regression model that accounts for the interactions between wetland types and ecosystem services. We test formally whether constructed wetlands provide the same level of values for flood protection, water quality improvement, and water storage and supply, i.e., the three main objectives for wetland construction (Hypothesis 1). We also assess whether ancillary benefits, such as support of recreational activities and biological diversity enhancement, provide a substantial contribution to the total economic value of constructed wetlands (Hypothesis 2).

The organization of the remainder of this paper is as follows. In Section 2 the characteristics of the dataset used are described by means of descriptive statistics (Section 2.1), an overview is given of the economic valuation studies of constructed wetlands (Section 2.2), and the meta-regression models are formulated (Section 2.3). Section 3 presents the results of a meta-regression estimation. Section 4 interprets the results. Section 5 concludes.

\section{Data and conceptual framework}

\subsection{The dataset of wetland valuation studies}

To support the analysis we constructed a dataset of wetland valuations consisting of 418 value observations from 170 valuation studies and 186 wetland sites. Figure 1 illustrates the geographical distribution of wetland values in the dataset. The largest number of observations is from North America (132), but significant numbers come from Asia (106), Europe (93) and Africa (53). South America (22) and Australasia (16) are somewhat underrepresented. Compared to the overall distribution of Ramsar wetlands of international importance, the geographical distribution of wetlands in the dataset is skewed towards sites located at temperate Northern latitudes and in the equatorial region. In particular, wetlands at latitudes 
higher than $45^{\circ} \mathrm{N}$ are underrepresented. Despite such a geographical bias, which reflects practice and availability of natural resource valuation studies, the database is considerably less biased towards North American wetlands than those developed and used in previous metaanalyses of wetland values. This reflects a substantial shift in the geographical distribution of wetland studies in recent years from North American sites towards European, Asiatic and African wetlands.

Figure 1. Number of observations of wetland values for five-year intervals from 1974 to 2009 and for geographical locations of valued wetlands

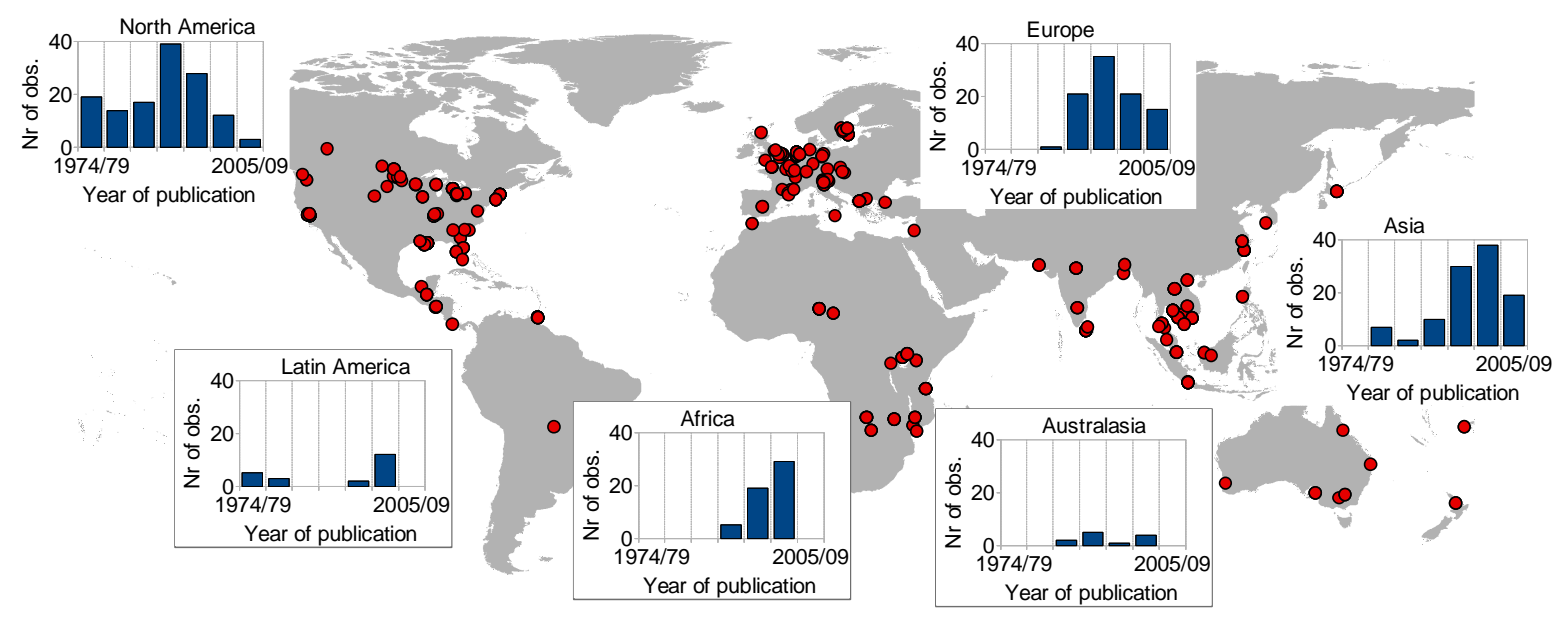

To identify candidate studies, we rely on a more stringent definition of wetlands than given by the Ramsar Convention, according to which any area of "marsh, fen, peatland or water, whether natural or artificial, permanent or temporary, with water that is static or flowing, fresh, brackish or salt, including areas of marine water the depth of which at low tide does not exceed six meters" is to be considered a wetland site. This definition potentially encompasses permanently inundated ecosystems such as all areas of coral reefs, sea-grass beds, most rivers and shallow lakes (Scott and Jones 1995). Such ecosystem types were excluded from this analysis, since they are not generally considered as wetlands and are not relevant for the analysis of constructed wetlands values.

The dataset developed by (Brander et al. 2006) provided the starting point for the analysis. The original dataset - consisting of 215 value observations from 80 studies - was substantially enlarged with new observations from recently published studies. Studies were retrieved through searching online valuation databases, libraries, and contacting authors. The wide range of market-based and non-market valuation studies considered is described in 
Section 2.3.1. Only primary valuation studies were included in the dataset, i.e., value transfer studies were not considered. In order to limit the risk of publication bias, the investigation also explored "grey literature", including 86 reports for both public and private institutions, consultancy studies, and unpublished research results. Efforts to retrieve studies not published in the English language led to the inclusion of 16 more studies.

\subsection{The literature on values of human-made wetlands}

The number of studies assessing the economic values of constructed or human-made wetlands is rather limited. Table 1 provides an overview of the available studies, some basic characteristics of the valued sites and the estimated values standardized to Purchasing Power Parity (PPP) adjusted units.

Table 1. Overview of valuation studies of constructed wetland ecosystems

\begin{tabular}{|c|c|c|c|}
\hline Wetland site & $\begin{array}{r}\text { Size, } \\
\text { ha }\end{array}$ & Value $^{\text {a }}$ & Reference \\
\hline $\begin{array}{l}\text { Cheimaditida and Zazari lakes, } \\
\text { Greece }\end{array}$ & 11,400 & $12,490-39,140$ & Ragkos et al. 2006 \\
\hline Cley marshes, UK & 176 & $1,008-3,904^{\mathrm{b}}$ & Klein and Bateman 1998 \\
\hline Constructed wetlands in Sweden & 6,400 & 4,080 & Byström 2000 \\
\hline $\begin{array}{l}\text { Little River/Rooty Creek, GA, } \\
\text { USA }\end{array}$ & 134 & 9,352 & MacDonald et al. 1998 \\
\hline De Wieden, Netherlands & 5,200 & $25-387$ & Hein et al. 2006 \\
\hline Empuriabrava, Spain & 7 & 78,321 & Seguí 2004 \\
\hline Hula, Israel & 24,000 & 163 & Baron et al. 1997 \\
\hline Lac du Der, France & 4,800 & 687 & Scherrer 2003 \\
\hline Lake Kerkini, Greece & 6,250 & 9,144 & Oglethorpe and Miliadou 2000 \\
\hline Oxelösund, Sweden & 22 & 12,635 & Cravener 1995 \\
\hline River Ancholme washlands, UK & 800 & 8,331 & $\begin{array}{l}\text { Posford Duvivier Environment } \\
1999\end{array}$ \\
\hline River Elbe floodplains, Germany & 55,000 & $114-2,066^{\mathrm{b}}$ & Meyerhoff and Dehnhardt 2004 \\
\hline River Nar washlands, UK & 150 & 8,201 & $\begin{array}{l}\text { Posford Duvivier Environment } \\
2000\end{array}$ \\
\hline $\begin{array}{l}\text { Upper and lower Bhoj wetlands, } \\
\text { India }\end{array}$ & 3,229 & $211-4,031^{b}$ & Verma 2001 \\
\hline Waza Logone, Cameroon & 20,000 & $1.7-101^{\mathrm{b}}$ & Loth 2004 \\
\hline Kala Oya basin, Sri Lanka & 285 & $1,908-13,269^{b}$ & Vidanage et al. 2004 \\
\hline $\begin{array}{l}\text { Hangzhou Botanical Garden, } \\
\text { China }\end{array}$ & 0.06 & $151,810-8,013,754^{b}$ & Yang et al. 2008 \\
\hline Whangamarino, New Zealand & 10,320 & $197-705$ & Kirkland 1988 \\
\hline
\end{tabular}

Several studies have assessed the benefits of wastewater treatment wetlands, either in terms of their water quality improvement service or ancillary benefits. The value of abating nitrogen 
load from agricultural sources and upgrading secondary municipal effluent for water recycling were assessed for Swedish wetlands draining into the Baltic Sea (Byström 2000) and for the Empuriabrava constructed wetlands in Catalonia, Spain, respectively (Seguí 2004). The value estimated with the travel cost method in Empuriabrava (78,321 USD/ha/annum) is substantially higher than the replacement costs for the Swedish sites (4080 USD/ha/annum). The value of upgrading and reusing the eutrophic effluent of an ornamental fishpond in Hangzhou, China, by means of a $600 \mathrm{~m}^{2}$ constructed wetland was estimated using the contingent valuation method (CVM) and the replacement cost method and ranged between 294,729 USD/ha/annum and 8,013,754 USD/ha/annum (Yang et al. 2008). The welfare impacts of other wastewater treatment wetlands services such as wildlife habitat enhancement and provision of passive values were assessed for constructed wetlands in the State of Georgia, USA (MacDonald et al. 1998), Oxelösund, Sweden (Cravener 1995), and Hangzhou, China (Yang et al. 2008). The estimates obtained with CVM ranged between 9,352 USD/ha/annum in Georgia and 151,830 USD/ha/annum in Hangzhou.

The value of constructed wetlands providing artificial impoundments for water storage was elicited in several studies in Europe and Asia. Estimates were highest for drinking and irrigation water supply, ranging between 4,031 USD/ha/annum in the Bhoj wetlands in India (Verma 2001) and 13,269 USD/ha/annum in Sri Lanka (Vidanage et al. 2004). Passive values and the value of supporting various types of recreational activities were elicited by means of CVM. The value of supporting recreational activities ranged between $687 \mathrm{USD} / \mathrm{ha} / \mathrm{annum}$ in Lac du Der, France (Scherrer 2003) and 2,048 USD/ha/annum in India (Verma 2001), while passive value estimates for Lake Kerkini in Greece were as high as 9,144 USD/ha/annum (Oglethorpe and Miliadou 2000).

Human-made wetlands created to provide flood protection and areas for flood storage in river floodplains were investigated in various locations in Europe. The value of flood protection along the Nar and Ancholme rivers in the UK was estimated to be 8,201 USD/ha/annum and 8,331 USD/ha/annum (Posford Duvivier Environment 1999, 2000). Other services provided by this type of wetland ecosystem include nutrient removal and biodiversity enhancement. The value of such services was estimated in 114-2,066 USD/ha/annum for nutrient removal and 1942 USD/ha/annum for biodiversity enhancement at various locations along the Elbe river in Germany (Meyerhoff and Dehnhardt 2004).

Another group of valuation studies concerns wetlands that are restored at the location of previously drained natural wetlands or that are not entirely artificial in origin but include constructed sections. Two studies eliciting the recreational value of a restored wetland in 
Israel (Baron et al. 1997) and the benefits of provisioning services in a restored floodplain wetland in Cameroon (Loth 2004) reported values of 163 USD/ha/annum and in the range 2$101 \mathrm{USD} / \mathrm{ha} /$ annum, respectively. Valuations of various services provided by wetlands that include human-made sections were conducted in various European countries and in New Zealand. For these sites, the conservation and enhancement of natural habitats was the most highly valued ecosystem service with monetary estimates ranging between 197 USD/ha/annum in Whangamarino, New Zealand (Kirkland 1988), and 27,678 USD/ha/annum in Cheimaditida and Zazari, Greece (Birol et al. 2006). Cultural services supporting various types of recreational activities were also highly valued (ranging from $295 \mathrm{USD} / \mathrm{ha} /$ annum in De Wieden, the Netherlands (Hein et al. 2006), and 3903 USD/ha/annum in the Cley marshes, UK (Klein and Bateman 1998).

The presented overview of the literature allows for the formulation of the hypotheses on the values of constructed wetlands that will be tested in Section 3. First, the highest values are reported for the provision of the specific services for which the wetlands are constructed, e.g. wastewater treatment wetlands provide high values for water quality improvement. Second, a large number of valuation studies focus on cultural services such as support of recreational activities, and enhancement of natural habitat and biodiversity, suggesting that they might be important components of the total economic value of such ecosystems. Accordingly, in Section 3 we will investigate whether (i) water quality improvement, water supply, and flood protection are the most highly valued services of constructed wetlands and whether (ii) cultural services are highly valued as well in such ecosystems.

\subsection{Specification of the meta-regression model and explanatory variables}

The base meta-analytical regression model is specified as follows:

$$
\ln \left(y_{i}\right)=a+b_{S} X_{S i}+b_{W} X_{W i}+b_{C} X_{C i}+u_{i}
$$

where the dependent variable $(\ln (y))$ is the natural logarithm of the wetland value expressed in 2003 US\$ per hectare per year. The subscript $i$ is an index for the 418 observations, $a$ is a constant term, $b_{S}, b_{W}$ and $b_{C}$ are vectors containing the coefficients of the explanatory variables, and $u$ is an error term that is assumed to be normally distributed and with a mean value of zero.

To allow for a comparison between wetland values that have been calculated in different years and expressed in different currencies and metrics - e.g. WTP per household per year, 
capitalized values, and marginal value per acre - values were standardized to a common metric and currency (Brander et al. 2006). Values referring to different years were deflated using appropriate factors from the World Bank Millennium Development Indicators (World Bank Group 2006), while differences in purchase power among the countries were accounted for by the PPP index provided by the Penn World Table (Heston et al. 2006).

Table 2 provides an overview of the explanatory variables. They consist of three categories, namely characteristics of (i) the primary study $X_{S}$, (ii) the valued wetland $X_{W}$ and (iii) the socioeconomic and geographical context $X_{C}$.

The study characteristics accounted for in the model include the valuation method used, the year of publication and a dummy distinguishing between marginal and average values. The array of valuation methods used in the primary studies to assess wetland values include market-based methods, revealed preference methods, and stated preference methods. A series of dummy variables is included in the meta-regression model to account for the heterogeneity of methods, since not all of them have a strong basis in welfare theory and produce estimates using different welfare measures. Also, to distinguish between marginal and average per hectare values, a dummy variable that equals one for marginal values is introduced (Brander et al. 2006).

Characteristics of the valued wetland site are the type and size of the wetland, the services provided, and the level of pressure exercised on it by human activities. The five basic wetlands systems of the Classification of Wetlands and Deepwater Habitats of the United States (Cowardin et al. 1979) are used in combination with a sixth category, which identifies human-made ecosystems. ${ }^{1}$ Since wetland ecosystems may include areas with different characteristics, the same observation may be classified under two or more wetland systems. Similarly, wetlands that include both man-made and natural sections (i.e., Whangamarino, Cley marshes, Cheimaditida-Zazari and de Wieden) are classified as simultaneously belonging to the category of constructed wetlands and to one (or more) of the categories of natural wetlands.

\footnotetext{
${ }^{1}$ The five basic wetland systems of the Cowardin classification are marine, estuarine, riverine, palustrine and lacustrine wetlands. Lacustrine systems include wetland and deepwater habitats, are situated in a topographic depression or a dammed river channel, and lack trees and widespread persistent emerging vegetation. Palustrine systems include all non-tidal wetlands dominated by trees, shrubs, and persistent emergent vegetation, and all such wetlands that occur in tidal areas where salinity due to ocean-derived salts is below $0.5 \%$. In classifying man-made wetlands as a separate category from natural wetlands we follow the Ramsar classification system of wetland types (available at http://www.ramsar.org/ris/key_ris_types.htm).
} 
Table 2. Explanatory variables used in the basic meta-regression model

\begin{tabular}{|c|c|c|c|c|}
\hline Group & Variable & Units and measurement & Mean (SD) & $N$ \\
\hline \multirow[t]{12}{*}{ Study $\left(X_{S}\right)$} & Contingent valuation method & Binary (range: 0 or 1 ) & $0.21(0.41)$ & 89 \\
\hline & Hedonic pricing & Binary (range: 0 or 1 ) & $0.01(0.10)$ & 4 \\
\hline & Travel cost method & Binary (range: 0 or 1 ) & $0.11(0.32)$ & 48 \\
\hline & Replacement cost & Binary (range: 0 or 1 ) & $0.17(0.38)$ & 71 \\
\hline & Net factor income & Binary (range: 0 or 1 ) & $0.13(0.34)$ & 54 \\
\hline & Production function & Binary (range: 0 or 1 ) & $0.07(0.25)$ & 28 \\
\hline & Market prices & Binary (range: 0 or 1 ) & $0.32(0.47)$ & 133 \\
\hline & Opportunity cost & Binary (range: 0 or 1 ) & $0.02(0.15)$ & 9 \\
\hline & Choice experiment & Binary (range: 0 or 1 ) & $0.03(0.17)$ & 13 \\
\hline & Year of publication & $\mathrm{Nr}$ of years since first valuation (1974) & $21.77(7.85)$ & 418 \\
\hline & Average & Omitted category & - & 366 \\
\hline & Marginal & Binary (range: 0 or 1 ) & $0.12(0.33)$ & 52 \\
\hline \multirow[t]{22}{*}{ Wetland $\left(X_{w}\right)$} & Estuarine & Binary (range: 0 or 1 ) & $0.31(0.46)$ & 129 \\
\hline & Marine & Binary (range: 0 or 1 ) & $0.23(0.42)$ & 98 \\
\hline & Riverine & Binary (range: 0 or 1 ) & $0.35(0.48)$ & 146 \\
\hline & Palustrine & Binary (range: 0 or 1 ) & $0.31(0.46)$ & 131 \\
\hline & Lacustrine & Binary (range: 0 or 1 ) & $0.25(0.43)$ & 105 \\
\hline & Constructed & Binary (range: 0 or 1 ) & $0.09(0.29)$ & 39 \\
\hline & Wetland size & Natural log of hectares & $9.26(3.12)$ & 418 \\
\hline & Flood control and storm buffering & Binary (range: 0 or 1 ) & $0.13(0.34)$ & 54 \\
\hline & Surface and groundwater supply & Binary (range: 0 or 1 ) & $0.12(0.32)$ & 49 \\
\hline & Water quality improvement & Binary (range: 0 or 1 ) & $0.12(0.33)$ & 52 \\
\hline & Commercial fishing and hunting & Binary (range: 0 or 1 ) & $0.24(0.43)$ & 99 \\
\hline & Recreational hunting & Binary (range: 0 or 1 ) & $0.17(0.38)$ & 71 \\
\hline & Recreational fishing & Binary (range: 0 or 1 ) & $0.17(0.37)$ & 69 \\
\hline & Harvesting of natural materials & Binary (range: 0 or 1 ) & $0.17(0.37)$ & 70 \\
\hline & Fuel wood & Binary (range: 0 or 1 ) & $0.07(0.26)$ & 31 \\
\hline & Non-consumptive recreation & Binary (range: 0 or 1 ) & $0.23(0.42)$ & 98 \\
\hline & Amenity and aesthetics & Binary (range: 0 or 1 ) & $0.10(0.30)$ & 43 \\
\hline & Natural habitat and biodiversity & Binary (range: 0 or 1 ) & $0.13(0.33)$ & 53 \\
\hline & Low pressure & Omitted category & - & 150 \\
\hline & Medium-low pressure & Binary (range: 0 or 1 ) & $0.42(0.49)$ & 175 \\
\hline & Medium-high predssure & Binary (range: 0 or 1 ) & $0.16(0.36)$ & 65 \\
\hline & High pressure & Binary (range: 0 or 1 ) & $0.07(0.25)$ & 28 \\
\hline \multirow[t]{3}{*}{ Context $\left(X_{C}\right)$} & GDP per capita ${ }^{a}$ & Natural log of 2003 dollars (PPP) & $9.32(1.34)$ & 418 \\
\hline & Population density ${ }^{\mathrm{b}}$ & Natural $\log$ of inhabitants in $50 \mathrm{~km}$ radius & $12.79(1.52)$ & 418 \\
\hline & Wetland abundance ${ }^{b}$ & Natural $\log$ of hectares in $50 \mathrm{~km}$ radius & $9.47(3.31)$ & 418 \\
\hline
\end{tabular}

Note: The number of observations for the variables valuation method, wetland type, and service provided do not add up to 418. This is due to the fact that individual observations may pertain to two or more levels.

$N=$ number of observations for each variable or variable level; $\mathrm{SD}=$ standard deviation

${ }^{\text {a }}$ At country level but for observations from USA (state) and EU countries (NUTS2)

${ }^{\mathrm{b}}$ Referring to year 2000

The ecosystem services provided by wetlands are classified based on the classification proposed in the Millennium Ecosystem Assessment (De Groot et al. 2006). The largest number of observations in the dataset relates to cultural services (264 observations) and provisioning services (257 observations), while relatively less information is available in the literature for regulating services (105 observations) and supporting services (45 observations). No valuation could be included for provision of genetic materials, climate regulation, erosion 
protection, spiritual and educational values, and support of pollinators.

The presence of pressure by human activities is accounted for in the meta-regression model as it may affect the ecological status of a wetland and the level of provision of ecosystem goods and services. Since direct observations of the ecological status are lacking for most of the wetlands in the dataset, an index was constructed that accounts for the degree of anthropogenic pressure exerted and may be interpreted as a broad, landscape assessment of a wetland's ecological conditions (Fennessy et al. 2004). The index takes into account three criteria: (i) the presence of alterations in the natural hydrologic regime of the wetland as induced, for instance, by the construction of dikes to regulate the water level in the wetland, (ii) whether the wetland is located in an urban or rural setting, and (iii) the site's protection status (viz. Ramsar site, national park, nature reserve or not protected). Each criterion is evaluated as a binary variable (controlled/natural hydrology, urban/rural, protected/not protected) and the index consists of a categorical predictor with four levels of pressure. The lowest level of pressure - i.e., all binary variables equal to zero - identifies wetland sites with natural hydrology, located in a rural setting and protected. At the other end of the range, "high pressure" identifies unprotected wetlands with controlled hydrology that are located in an urban environment. The categories "medium low" and "medium high" pressure identify intermediate states.

Three contextual variables are included in the meta-regression model: real Gross Domestic Product (GDP) per capita; number of inhabitants surrounding the wetland; and total wetland area in the region under investigation. Contextual characteristics are expected to significantly influence the valuation estimates since environmental valuation studies carried out at different geographical sites and involving populations with different socioeconomic characteristics and consumer preferences typically produce different outcomes (Brouwer 2000). The values of real GDP per capita used in the meta-regression model are measured in 2003 US\$ and calculated at the national level with the exception of observations from the US and EU countries, for which values are calculated for the individual states and NUTS2 regions, respectively. The total population and abundance of wetland ecosystems in the surroundings of the valued wetland are assessed in a radius of $50 \mathrm{~km}$ around the geographic center of the wetland applying GIS techniques to the Global Demography Project map (CIESIN 2005) and the Global Lakes and Wetlands Database map (Lehner and Döll 2004).

Figure 2 provides some descriptive statistics that summarize the variability of wetland values, expressed in 2003 USD, according to wetland size and context characteristics. A positive correlation with the wetland value is found for per capita GDP and total population 
living in a $50 \mathrm{~km}$ radius around the wetland centre, and a negative correlation for wetland size and wetland area within a $50 \mathrm{~km}$ radius. As indicated by the low values of goodness of fit, however, none of the variables alone explains a large proportion of the variation in the values.

Figure 2. Standardized wetland value plotted against real per capita GDP (above left), wetland size (above right), total population (below left) and wetland abundance (below right) in a $50 \mathrm{~km}$ radius from the center of the valued wetland site
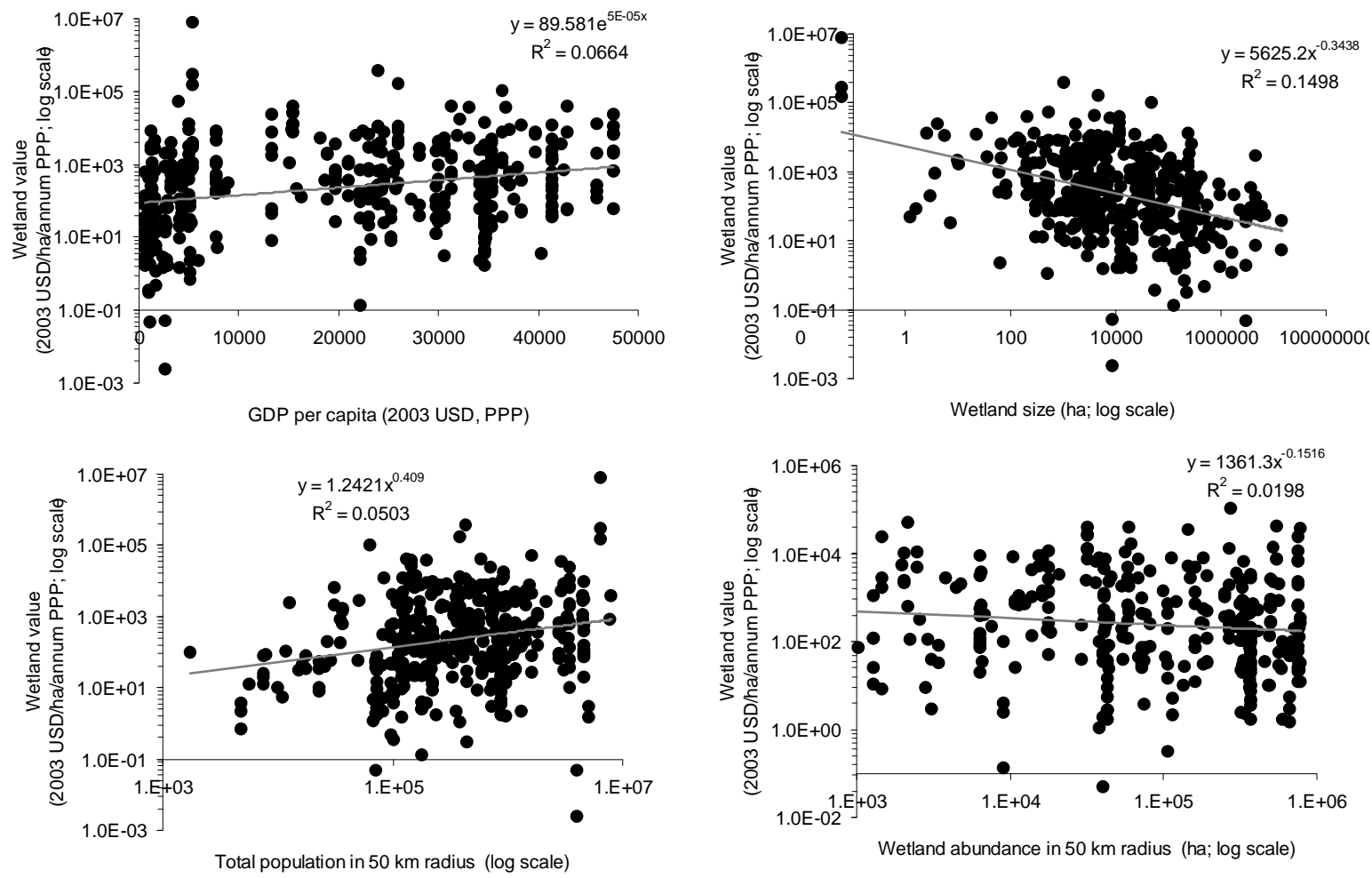

Aside from the base meta-regression model (Equation 1), we estimate an extended model that includes a series of cross-effect variables that capture the relationship between the level of provision of a specific wetland service and the type of wetland that provides it. In addition to the study and context characteristics discussed for the basic meta-regression model, the extended model includes 66 dummy variables (11 wetland services multiplied by 6 wetland types). The use of cross-products in meta-analysis is a simple and attractive way to statistically test for possible interactions between explanatory variables (Nunes et al. 2009). 


\section{Econometric results}

The results obtained with the basic meta-regression model described in equation (1) using ordinary least squares (OLS) are presented in Table 3. In the estimated semi-logarithmic model, the coefficients measure the constant proportional or relative change in the dependent variable for a given absolute change in the value of the explanatory variable. For the explanatory variables expressed as logarithms, the coefficients represent elasticities, that is, the percentage change in the dependent variable given a one-percentage change in the explanatory variable.

Table 3 presents the results for two different specifications of the base model. Model A includes all explanatory variables in Table 2 and all observations. In model B, the dummy variables identifying the valuation method are dropped from the regression since they are found to be statistically insignificant in model A and moderately correlated with several ecosystem services. The low significance of the coefficients on valuation methods suggests that methodological heterogeneity in the primary studies does not influence the regression results in any substantial sense. ${ }^{2}$ Table 3 presents coefficients and standard errors obtained with OLS. Conducting the regressions with Huber/White/sandwich estimators results in the coefficients of 'production function' and 'opportunity cost' becoming significant at the $10 \%$ level in model A. 'Water quality improvement', on the other hand, becomes insignificant. The regression with robust estimators does not change the significance of any of the estimated coefficients in model B.

\footnotetext{
${ }^{2}$ Table 3 shows the results obtained with the regression of 416 observations rather than 418 , since two value observations derived from a mangrove restoration study in Vietnam (Hoang Tri et al. 1998) were identified as regression outliers and influential on the regression coefficients. These two observations were dropped from the dataset which slightly increased the explanatory power of the model (from $R^{2}=0.47$ to $R^{2}=0.49$ ) without affecting sign and significance of the coefficient estimates, with the exception of the variable 'opportunity cost' which becomes insignificant.
} 
Table 3. Results obtained with the basic meta-regression model of wetland values

\begin{tabular}{|c|c|c|c|c|c|c|c|c|c|c|c|c|}
\hline \multirow[b]{2}{*}{ Variable } & \multicolumn{3}{|c|}{ Basic model (A) } & \multicolumn{3}{|c|}{ Basic model (B) } & \multicolumn{3}{|c|}{$\begin{array}{c}\text { Model }(\mathrm{C}) \text {, } \\
\text { weighted } \\
\text { observations }\end{array}$} & \multicolumn{3}{|c|}{$\begin{array}{l}\text { Model (D), first } \\
\text { observation only }\end{array}$} \\
\hline & Coeff. & & SE & Coeff. & & $\mathrm{SE}$ & Coeff. & & SE & Coeff. & & SE \\
\hline Contingent valuation method & 0.043 & & 0.531 & - & & - & - & & - & - & & - \\
\hline Hedonic pricing & -1.342 & & 1.209 & - & & - & - & & - & - & & - \\
\hline Travel cost method & -0.633 & & 0.530 & - & & - & - & & - & - & & - \\
\hline Replacement cost & -0.472 & & 0.527 & - & & - & - & & - & - & & - \\
\hline Net factor income & -0.411 & & 0.489 & - & & - & - & & - & - & & - \\
\hline Production function & -0.902 & & 0.560 & - & & - & - & & - & - & & - \\
\hline Market prices & -0.632 & & 0.461 & - & & - & - & & - & - & & - \\
\hline Opportunity cost & -1.231 & & 0.810 & - & & - & - & & - & - & & - \\
\hline Choice experiment & 1.188 & & 0.812 & - & & - & - & & - & - & & - \\
\hline Year of publication & -0.054 & $* * *$ & 0.018 & -0.041 & *** & 0.016 & -0.029 & & 0.027 & -0.056 & $* *$ & 0.026 \\
\hline Marginal & 1.032 & $* * *$ & 0.375 & 0.713 & ** & 0.338 & 0.643 & & 0.479 & 0.445 & & 0.460 \\
\hline Estuarine & 0.321 & & 0.290 & 0.270 & & 0.288 & 0.452 & & 0.480 & 0.443 & & 0.473 \\
\hline Marine & 0.775 & $* * *$ & 0.282 & 0.754 & ***** & 0.280 & 0.789 & $*$ & 0.462 & 0.500 & & 0.475 \\
\hline Riverine & 0.360 & & 0.259 & 0.380 & & 0.257 & 0.434 & & 0.422 & 0.253 & & 0.415 \\
\hline Palustrine & -0.380 & & 0.282 & -0.480 & $*$ & 0.271 & -0.280 & & 0.452 & -0.310 & & 0.427 \\
\hline Lacustrine & 0.268 & & 0.277 & 0.332 & & 0.268 & 0.364 & & 0.430 & 0.431 & & 0.419 \\
\hline Constructed & 1.167 & $* * *$ & 0.411 & 1.023 & $* *$ & 0.403 & 1.188 & * & 0.627 & 1.174 & * & 0.616 \\
\hline Wetland size & -0.247 & $* * *$ & 0.042 & -0.234 & **** & 0.040 & -0.245 & **** & 0.063 & -0.176 & *** & 0.061 \\
\hline Flood control, storm buffering & 0.432 & & 0.348 & 0.432 & & 0.329 & 0.286 & & 0.538 & 0.303 & & 0.543 \\
\hline Surface \& groundwater supply & -0.037 & & 0.355 & -0.099 & & 0.334 & -0.430 & & 0.602 & -0.453 & & 0.546 \\
\hline Water quality improvement & 0.677 & $*$ & 0.388 & 0.727 & ** & 0.332 & 0.720 & & 0.566 & 0.685 & & 0.596 \\
\hline Commercial fishing \& hunting & 0.301 & & 0.276 & 0.266 & & 0.253 & 0.344 & & 0.424 & 0.501 & & 0.435 \\
\hline Recreational hunting & -0.905 & $* * *$ & 0.347 & -1.007 & **** & 0.334 & -0.743 & & 0.557 & -1.063 & $*$ & 0.556 \\
\hline Recreational fishing & 0.033 & & 0.355 & -0.082 & & 0.349 & -0.060 & & 0.565 & 0.213 & & 0.562 \\
\hline Harvesting of natural materials & -0.140 & & 0.299 & -0.202 & & 0.286 & -0.143 & & 0.507 & -0.476 & & 0.499 \\
\hline Fuel wood & -1.031 & $* *$ & 0.418 & -0.968 & ** & 0.416 & -0.842 & & 0.709 & -1.197 & $*$ & 0.696 \\
\hline Non-consumptive recreation & 0.381 & & 0.332 & 0.670 & ** & 0.303 & 0.287 & & 0.466 & 0.327 & & 0.458 \\
\hline Amenity and aesthetics & 0.528 & & 0.424 & 0.529 & & 0.392 & 0.969 & $*$ & 0.544 & 0.831 & & 0.534 \\
\hline Natural habitat, biodiversity & 0.580 & & 0.375 & 1.143 & **** & 0.330 & 1.168 & ** & 0.464 & 1.285 & **** & 0.462 \\
\hline Medium-low human pressure & 0.564 & ${ }^{* *}$ & 0.258 & 0.572 & ** & 0.256 & 0.805 & * & 0.426 & 1.167 & *** & 0.409 \\
\hline Medium-high human pressure & 1.130 & $* * *$ & 0.359 & 1.243 & **** & 0.358 & 1.260 & $* *$ & 0.575 & 1.489 & *** & 0.554 \\
\hline High human pressure & 2.093 & $* * *$ & 0.505 & 1.992 & **** & 0.500 & 1.922 & $* *$ & 0.871 & 2.453 & *** & 0.854 \\
\hline GDP per capita & 0.295 & ${ }^{* *}$ & 0.118 & 0.358 & **** & 0.110 & 0.237 & & 0.199 & 0.056 & & 0.201 \\
\hline Population in $50 \mathrm{~km}$ radius & 0.399 & $* * *$ & 0.075 & 0.399 & **** & 0.073 & 0.321 & *** & 0.123 & 0.317 & *** & 0.119 \\
\hline Wetland area in $50 \mathrm{~km}$ radius & -0.064 & $*$ & 0.036 & -0.058 & & 0.035 & -0.076 & & 0.058 & -0.099 & $*$ & 0.055 \\
\hline Constant & 0.854 & & 1.856 & -0.681 & & 1.652 & 1.245 & & 2.962 & 3.390 & & 2.872 \\
\hline Nr. of observations & 416 & & & 416 & & & $168^{\mathrm{a}}$ & & & 168 & & \\
\hline$R^{2}$ & 0.49 & & & 0.47 & & & 0.46 & & & 0.48 & & \\
\hline Adjusted $R^{2}$ & 0.45 & & & 0.44 & & & 0.36 & & & 0.38 & & \\
\hline
\end{tabular}

Note: OLS results; SE = standard error; Coeff. = coefficient; significance is indicated with " ${ }^{* * *}$ and " for 1,5 and $10 \%$ statistical significance levels respectively; ${ }^{a}$ Takes into account the different weights given to the 416 observations. 
In the meta-regression models $\mathrm{A}$ and $\mathrm{B}$ we implicitly assume the 416 observations to be independent. Although dependency issues between observations derived from the same study are unlikely to play a key role in this study since the average and maximum number of observations per study -2.4 and 12 , respectively - are small compared to the size of the sample, a multi-level regression of an earlier version of the dataset indicated the presence of significant authorship effects (Ghermandi et al. 2008). To investigate the potential influence of correlation between observations on the regression results we conducted two additional regressions using some of the means suggested in the literature to account for dependency across observations (Nelson and Kennedy 2008). First, we conducted a regression weighting observations, in which each study in the dataset receives equal weight, instead of each observation as in ordinary OLS (model C). Second, we performed a regression in which only one observation per study is selected (model D). Only the first observation in the dataset for each study was selected. The regression results in Table 3 show that in both regressions the sign of the coefficients is unchanged with respect to the ordinary OLS regression, with exception of the sign of 'recreational fishing' in model D. The significance of several variables is affected. Since, however, the significance of the coefficients that are most relevant for the purpose of this study remains unchanged, we conclude that correlation between observations does not have a substantial influence on the results of this study.

A series of diagnostic tests were performed in order to investigate the robustness of the ordinary OLS regression results of model B. The analysis of residuals indicates that they are distributed between a maximum value of 3.167 and a minimum of -3.094 with mean $0.0005 \pm 1.003$. The Shapiro-Wilk test $(\mathrm{p}-\mathrm{level}=0.860)$ does not reject the assumption of normal distribution of the residuals. Similarly, the null hypothesis of homogenous variance of the residuals cannot be rejected by means of White's test (p-level $=0.143$ ) and Breusch-Pagan test (Prob. $\left.>\chi^{2}=0.764\right)$. The five largest leverages and the five most influential observations on estimated parameters were identified and the meta-regression with basic model B was rerun excluding them from the analysis. All signs and significance of the coefficients were unchanged, with the exception of the coefficients of flood control and wetland area in $50 \mathrm{~km}$ radius, which become, respectively, significant at the $10 \%$ and $5 \%$ level in the regression without the most influential observations. The coefficient of palustrine wetlands becomes insignificant. Multicollinearity between the variables is not an issue of concern (max VIF = 2.24) and visual inspection of the plots of standardized residuals against explanatory variables did not show substantial deviation from linear behavior. For what concerns model specification, both the link test for model specification $(\mathrm{p}-\mathrm{level}=0.571)$ and the regression 
specification error test for omitted variables (Prob $>\mathrm{F}=0.908$ ) do not suggest specification errors. Finally, since the main focus of the study is on constructed wetlands, we repeated the regression with model B excluding valuations of the constructed wetland in Hangzhou, China (Yang et al. 2008), which are outliers in the estimated values (see Table 1). The significance of all coefficients is unchanged with exception of the coefficients of palustrine wetlands and area of wetlands in $50 \mathrm{~km}$ radius, which become respectively insignificant and significant at $5 \%$ level.

Table 4 presents the results for the extended meta-regression model with cross-effects. The focus is on the cross-effect variables since the signs and significance of the coefficient estimates for study and context variables remain unchanged as compared to the base metaregression model B.

Table 4. Coefficients of the cross-effects variables in the extended model

\begin{tabular}{|c|c|c|c|c|c|c|}
\hline Wetland type & $\begin{array}{c}\text { Estuarine } \\
\text { Coeff. }\end{array}$ & $\begin{array}{c}\text { Marine } \\
\text { Coeff. }\end{array}$ & $\begin{array}{c}\text { Riverine } \\
\text { Coeff. }\end{array}$ & $\begin{array}{c}\text { Palustrine } \\
\text { Coeff. }\end{array}$ & $\begin{array}{c}\text { Lacustrine } \\
\text { Coeff. }\end{array}$ & $\begin{array}{c}\text { Constructed } \\
\text { Coeff. }\end{array}$ \\
\hline Flood control and storm buffering & 0.011 & $1.326^{*}$ & 0.666 & -0.486 & -1.225 & $2.845^{* *}$ \\
\hline Surface and groundwater supply & -1.201 & -0.036 & -0.497 & 0.475 & 0.405 & 0.958 \\
\hline Water quality improvement & $3.128^{* * * *}$ & 0.305 & 0.033 & 0.717 & -0.555 & 1.716 \\
\hline Commercial fishing and hunting & 0.410 & 0.652 & $1.177^{* *}$ & $-2.475^{* * * *}$ & 0.383 & 0.266 \\
\hline Recreational hunting & -0.294 & -0.374 & -0.509 & -0.833 & -0.426 & -0.355 \\
\hline Recreational fishing & -0.019 & -0.760 & 0.337 & 0.045 & 0.790 & $-3.990^{*}$ \\
\hline Harvesting of natural materials & -0.595 & 0.612 & -0.288 & 0.218 & -0.234 & -0.565 \\
\hline Fuel wood & -0.901 & 0.136 & 0.622 & $-3.368^{* *}$ & -2.126 & - \\
\hline Non-consumptive recreation & 0.072 & -0.005 & 0.792 & 0.937 & 0.132 & 0.525 \\
\hline Amenity and aesthetics & 1.873 & 0.158 & -0.193 & -0.177 & -0.257 & -0.109 \\
\hline Natural habitat and biodiversity & -1.189 & $1.831^{* *}$ & 0.434 & 0.256 & -0.011 & $2.261^{* *}$ \\
\hline
\end{tabular}

Note: OLS results; Coeff. = coefficient; - - = no observation available; $R^{2}=0.55 ; A d j . R^{2}=0.46$; significance is indicated with $^{* * *},{ }^{* *}$ and ${ }^{*}$ for 1,5 and $10 \%$ statistical significance levels respectively.

The Shapiro-Wilk test $(\mathrm{p}-$ level $=0.049)$ indicates a certain deviation in the distribution of the residuals from the normal distribution. Since, however, the analysis of interquartile range does not identify any severe outlier in the sample, such deviation is considered of minor importance for the interpretation of the results. Further testing does not provide indications of heteroscedasticity, multicollinearity or model misspecification. Excluding the observations from (Yang et al. 2008) causes the coefficient on the cross-effect variable linking constructed wetlands and water quality improvement to become statistically insignificant. 


\section{Interpretation of the results}

The present study provides an original contribution in terms of identification of the main determinants of the values of natural and constructed wetland ecosystems both in absolute and relative terms, using meta-analysis. Compared to previous meta-analyses of wetland values, we have substantially extended the number of primary studies on which the meta-analysis builds and have introduced a number of important additional explanatory variables, which we found to be statistically significant in variation in the valuation of wetlands.

Some of the results of previous studies are confirmed by this meta-analysis. The coefficient on water quality improvement indicates high values for this service (Brouwer et al. 1999; Woodward and Wui 2001), while provision of fuel wood and recreational hunting are less valued (Brander et al. 2006; Woodward and Wui 2001). In addition, in this study we found that non-consumptive recreational activities and the provision of natural habitat and biodiversity are highly valued. The coefficients of the variables 'wetland size' and 'marginal' indicate decreasing returns to scale and that marginal values are higher than average values (Brander et al. 2006). Also, values are sensitive to income effects and increase with the population living in the surrounding of a wetland (Brander et al. 2006). Although the explanatory powers of different meta-analyses are strictly speaking not directly comparable since they are based on different samples and underlying variation in the endogenous variable, for the sake of rough comparison it can be noted that the explanatory power of this metaregression is higher than in (Brouwer et al. 1999) $\left(\mathrm{R}^{2}=0.38\right)$ and slightly lower than in $\left(\mathrm{R}^{2}=\right.$ 0.58 for meta-regression model $C)$ and (Brander et al. 2006) $\left(R^{2}=0.55\right.$; Adj. $\left.R^{2}=0.45\right)$.

The principal original contributions of this study are in the analysis of substitution effects, value variation with anthropogenic pressure, and valuation of constructed wetlands. The assessed negative relationship between the proximity of other wetlands and the value of the wetland indicates the presence of substitution effects for at least some of the wetland services. The abundance of wetland ecosystems in a certain region reflects the uniqueness of a wetland environment and may influence people's perceptions and preferences due to the presence of other sites that can act as a substitute for some of the services provided.

The coefficients for the environmental pressure variables are all positive and increase with pressure indicating that a high pressure of human activities on the wetland produces high values. Possible explanations for this are that human activities contribute to translate potential uses into values or that human interventions in a wetland often improve the level of provision of specific wetland services, such as water quality improvement in the case of treatment constructed wetlands. Furthermore, wetlands surrounded by densely populated areas and with 
unrestricted access - thus with high environmental pressure according to the index proposed in this study - are likely to be relatively easily accessible for the enjoyment of their recreational functions. High anthropogenic pressure on a wetland, however, raises questions about the sustainability of values. Regrettably, this issue cannot be addressed with the snapshots of values inferred from the valuation studies.

Among wetland types, constructed wetlands have the highest values followed by marine wetlands. A possible explanation for the high value of constructed wetlands is that artificial ecosystems are usually constructed with the specific purpose of providing services for human use and benefits. The analysis of the results of the extended model allows us to identify that flood control, storm buffering, and water quality improvement are highly valued in constructed wetland ecosystems. The first hypothesis formulated in Section 1 which states that constructed and natural wetlands provide the same level of values for such services (Hypothesis 1) is thus rejected. In our analysis, constructed wetlands are substitutes respectively of marine and estuarine wetlands in terms of the provision of flood control and water quality improvement services. Remarkably, the coefficient of provision of natural habitat and biodiversity in constructed wetlands is positive and highly statistically significant. Although the coefficient of recreational activities in constructed wetlands is not significant (though positive), this supports the hypothesis that the ancillary cultural benefits of constructed wetlands are substantial components of their total economic value (Hypothesis 2). This valuation result signals the potential value of these ancillary ecosystem services and thus the importance of taking them into account in the design and evaluation of alternative policy scenarios and cost benefit exercise.

\section{Conclusions}

This study provides the most comprehensive review of wetland valuation studies that has been completed to date, with the aim to provide more insight about the comparative values of natural and constructed wetland ecosystems. The dataset includes 418 observations from 186 wetland sites worldwide, which were derived from 170 primary valuation studies.

A meta-regression was performed to identify and estimate the relative importance of the determinants of wetland values. Marine and constructed wetlands are more highly valued than

other wetland types. Water quality improvement, non-consumptive recreation and provision of natural habitat and biodiversity provide high benefits, while recreational hunting and fuel wood provision are less valued ecosystem services. Values show decreasing returns to scale 
and are sensitive to income effects and to the total population living in the surroundings of a wetland.

This study provides a substantially new contribution in relation to previous meta-analyses of the wetland valuation literature in terms of number of observations, geographical coverage, wetland class and integrity, and the measurement of scarcity effects. This meta-analysis is the first to account for the possible impact of substitution effects, which are found to significantly affect wetland values. The analysis of the index of pressure from human activities that was developed for this study led to the conclusion that wetland values increase with human pressures and uses. We suggest that this may be linked to an improved level of provision of specific services and the intensity of use of wetlands. Questions about the sustainability of the uses and values reported in the valuation studies for wetlands with high environmental pressure could not however be answered in the frame of this meta-analysis.

For the first time, constructed wetlands are included in a meta-analysis of wetland values. Confirming our expectations, constructed wetlands are highly valued for flood control, storm buffering, and water quality improvement. Remarkably, they are also highly valued for provision of natural habitat and biodiversity, which are not primary goals in the creation of such ecosystems. We conclude that the evaluation of constructed wetlands should not be limited to their direct benefits, but account for the fact that the (re-)construction of wetlands and their habitat may have a significant role in terms of local biodiversity enhancement. This suggests a high potential for landscape and waterscape architecture projects to bring substantial welfare gains to communities with limited access to natural ecosystems such as those in urbanized areas.

\section{References}

Bal F, Nijkamp P (2001) In search of valid results in a complex economic environment: The potential of meta-analysis and value transfer. European Journal of Operational Research 128:364-384.

Balcombe CK, Anderson JT, Fortney RH, Kordek WS (2005) Wildlife use of mitigation and reference wetlands in West Virginia. Ecological Engineering 25:85-99.

Baron MG, Zaitsev N, Schechter M (1997) Expected recreational benefits of the Hula project: Economic analysis Final report to the Hula Project Authority. 
Benyamine M, Bäckström M, Sanden P (2004) Multi-objective environmental management in constructed wetlands. Environmental monitoring and assessment 90:171-185.

Bergstrom JC, Taylor LO (2006) Using meta-analysis for benefits transfer: Theory and practice. Ecological Economics 60:351-360.

Birol E, Karousakis K, Koundouri P (2006) Using a choice experiment to account for preference heterogeneity in wetland attributes: The case of Cheimaditida wetland in Greece. Ecological Economics 60:145-156.

Brander LM, Florax RJGM, Vermaat JE (2006) The empirics of wetland valuation: A comprehensive summary and a meta-analysis of the literature. Environmental and Resource Economics 33:223-250.

Brooks RP, Wardrop DH, Cole CA, Campbell DA (2005) Are we purveyors of wetland homogeneity? A model of degradation and restoration to improve wetland mitigation performance. Ecological Engineering 24:331-340.

Brouwer R (2000) Environmental value transfer: state of the art and future prospects. Ecological Economics 32:137-152.

Brouwer R, Langford IH, Bateman IJ, Turner RK (1999) A meta-analysis of wetland contingent valuation studies. Regional Environmental Change 1:47-57.

Byström O (2000) The replacement value of wetlands in Sweden. Environmental and Resource Economics 16:347-362.

Campbell DA, Cole CA, Brooks RP (2002) A comparison of created and natural wetlands in Pennsylvania, USA. Wetlands Ecology and Management 10:41-49.

CIESIN (2005) Gridded Population of the World Version 3. Center for International Earth Science Information Network (CIESIN), Columbia University; International Food Policy Research Institute (IFPRI), the World Bank; and Centro Internacional de Agricultura Tropical (CIAT). Socioeconomic Data and Applications Center (SEDAC), Columbia University, Palisades, NY.

Confer SR, Niering WA (1992) Comparison of created and natural freshwater emergent wetlands in Connecticut (USA). Wetlands Ecology and Management 2:143-156.

Cowardin LM, Carter V, Golet FC, LaRoe ET (1979) Classification of wetlands and deepwater habitats of the US. U.S. Department of the Interior, Fish and Wildlife Service, Washington, D.C.

Cravener M (1995) Samhällsekonomisk värdering av den anlagda våtmarken i Oxelösund, en tillämpning av Contingent Valuation metoden Master thesis, Department of Economics, Stockholm University. 
De Groot RS, Stuip MAM, Finlayson CM, Davidson N (2006) Valuing wetlands: guidance for valuing the benefits derived from wetland ecosystem services. Ramsar Technical Report/CBD Technical Series 3/27, Gland, Switzerland.

Fennessy MS, Jacobs AD, Kentula ME (2004) Review of rapid methods for assessing wetland condition. EPA/620/R-04/009, US Environmental Protection Agency, Washington, DC.

Ghermandi A, van den Bergh JCJM, Brander LM, De Groot HLF, Nunes PALD (2008) The economic value of wetland conservation and creation: A meta-analysis. Fondazione Eni Enrico Mattei Working Papers:238.

Hammer DA, Bastian RK (1989) Wetlands ecosystems: natural water purifiers. In: Constructed Wetlands for Wastewater Treatment: Municipal, Industrial and Agricultural. Lewis Publishers, Michigan, pp. 6-20.

Hein L, Van Koppen K, De Groot RS, Van Ierland E (2006) Spatial scales, stakeholders and the valuation of ecosystem services. Ecological Economics 57:209-228.

Heston A, Summers R, Aten B (2006) Penn world table version 6.2. Center for International Comparisons of Production, Income and Prices at the University of Pennsylvania.

Hoang Tri N, Adger WN, Kelly PM (1998) Natural resource management in mitigating climate impacts: the example of mangrove restoration in Vietnam. Global Environmental Change 8:49-61.

Hoehn JP (2006) Methods to address selection effects in the meta regression and transfer of ecosystem values. Ecological Economics 60:389-398.

Johnston RJ, Besedin EY, Wardwell RF (2003) Modeling relationships between use and nonuse values for surface water quality: A meta-analysis. Water Resources Research 39:1363.

Kadlec RH, Knight RL (1996) Treatment wetlands: theory and implementation. Lewis Publishers, Boca Raton, FL.

Kirkland WT (1988) Preserving the Whangamarino Wetland; an Application of the Contingent Valuation Method. Master Thesis, Massey University, New Zealand.

Klein RJT, Bateman IJ (1998) The recreational value of Cley marshes nature reserve: an argument against managed retreat? Journal of the Chartered Institution of Water and Environmental Management 12:280-285.

Knight RL (1997) Wildlife habitat and public use benefits of treatment wetlands. Water Science \& Technology 35:35-43. 
Knight RL, Clarke Jr RA, Bastian RK (2001) Surface flow(SF) treatment wetlands as a habitat for wildlife and humans. Water Science \& Technology 44:27-37.

Lehner B, Döll P (2004) Development and validation of a global database of lakes, reservoirs and wetlands. Journal of Hydrology 296:1-22.

Loth PE (2004) The return of the water: restoring the Waza Logone Floodplain in Cameroon The World Conservation Union (IUCN).

MacDonald HF, Bergstrom JC, Houston JE (1998) A proposed methodology for measuring incremental environmental benefits from using constructed wetlands to control agricultural non-point-source pollution. Journal of Environmental Management 54:259-267.

Meyerhoff J, Dehnhardt A (2004) The European Water Framework Directive and economic valuation of wetlands. In: Proc. of 6th BIOECON Conference Cambridge.

Nelson JP, Kennedy PE (2008) The use (and abuse) of meta-analysis in environmental and natural resource economics: an assessment. Working Paper Series, SSRN eLibrary: http://ssrn.com/abstract=1117490.

Nunes PALD, Ojea E, Loureiro ML (2009) Mapping of Forest Biodiversity Values: A Plural Perspective. Fondazione Eni Enrico Mattei Working Papers:264.

Oglethorpe DR, Miliadou D (2000) Economic Valuation of the Non-use Attributes of a Wetland: A Case-study for Lake Kerkini. Journal of Environmental Planning and Management 43:755-767.

Posford Duvivier Environment (1999) River Ancholme flood storage area progression Environment Agency, UK, report no. E3475/01/001.

Posford Duvivier Environment (2000) River Nar improvement scheme Environment Agency, UK, draft engineers report.

Ragkos A, Psychoudakis A, Christofi A, Theodoridis A (2006) Using a functional approach to wetland valuation: the case of Zazari-Cheimaditida. Regional Environmental Change 6:193-200.

Rosenberger RS, Loomis JB (2000) Panel Stratification In Meta-Analysis Of Economic Studies: An Investigation Of Its Effects In The Recreation Valuation Literature. Journal of Agricultural and Applied Economics 32.

Rosenberger R, Loomis J (2000) Using meta-analysis for benefit transfer: In-sample convergent validity tests of an outdoor recreation database. Water Resources Research:1097-1107. 
Scheierling SM, Loomis JB, Young RA (2006) Irrigation water demand: A meta-analysis of price elasticities. Water Resources Research 42:W01411.

Scherrer S (2003) Evaluation économique des aménités récréatives d'une zone humide intérieure : le cas du lac du Der Ministère de l'Ecologie et du Développement Durable, IFOP report no. 03-E05.

Scott DA, Jones TA (1995) Classification and inventory of wetlands: A global overview. Plant Ecology 118:3-16.

Seguí L (2004) Sistemas de regeneración y reutilización de aguas residuales. Metodología para el análisis técnico-económico y casos Tesis Doctoral. Departamento de Ingeniería Agroalimentaria y Biotecnología. Universidad Politécnica de Cataluña.

Smith VK, Pattanayak SK (2002) Is meta-analysis a Noah's ark for non-market valuation? Environmental and Resource Economics 22:271-296.

Stanley TD (2005) Beyond publication bias. Journal of Economic Surveys 19:309-345.

Turner K (1991) Economics and Wetland Management. Ambio 20:59-63.

Verma M (2001) Economic valuation of Bhoj wetlands for sustainable use. Unpublished project report for World Bank assistance to Government of India, Environmental Management Capacity-Building. Bhopal: Indian Institute of Forest Management.

Vidanage S, Perera S, Kallesoe M (2004) Kala Oya River basin, Sri Lanka: Integrating wetland economic values into river basin management. Environmental Economics Programme, IUCN Sri Lanka Country Office, Colombo.

White House Office on Envtl. Policy (1993) Protecting America's wetlands: A Fair, Flexible, and Effective Approach (Aug. 24, 1993). Advance Notice of Proposed Rulemaking on the Clean Water Act Regulatory Definition of "Waters of the United States,” 68 Fed. Reg. 1991.

Woodward RT, Wui YS (2001) The economic value of wetland services: a meta-analysis. Ecological Economics 37:257-270.

World Bank Group (2006) World development indicators 2006. World Bank Publications.

Yang W, Chang J, Xu B, Peng C, Ge Y (2008) Ecosystem service value assessment for constructed wetlands: A case study in Hangzhou, China. Ecological Economics 68:116-125. 